\title{
Spawning environmental conditions of Sardinella aurita at the northern limit of its distribution range, the western Mediterranean
}

\author{
Ana Sabatés*, Jordi Salat, Vanesa Raya, Mikhail Emelianov, Mariona Segura-Noguera
}

Institut de Ciències del Mar, CSIC, Passeig Marítim 37-49, 08003 Barcelona, Spain

\begin{abstract}
In the last $20 \mathrm{yr}$, an increasing abundance and northward expansion of Sardinella aurita has been reported in the western Mediterranean. The present study characterizes the spawning habitat of $S$. aurita at the northern limit of their geographic distribution and determines the hydrodynamic conditions that could control their northward expansion in the western Mediterranean. Data along the Catalan shelf and slope were obtained in 4 oceanographic cruises conducted in the summers of 2003 and 2004. A clear preference for spawning in coastal areas shallower than $100 \mathrm{~m}$ was determined, with larvae showing a wider distribution extending offshore up to the position of the $150 \mathrm{~m}$ isobath. The greatest abundance of eggs and larvae was found in the southern half of the area on the wide shelf near the mouth of the Ebro River. This zone was characterized by high values of surface chlorophyll $a$ in association with relatively low salinity waters from the Ebro River. In the northern part of the area, a thermal front across the shelf, with higher sea surface temperatures on its southern side, marked the northern limit of egg and larvae distribution. The northern side of this front was under the direct influence of the shelf-slope current, advecting slope waters from the north, while its southern side was dominated by coastal water. Larvae carried by coastal waters tended to concentrate near the convergence associated with the front. Thus, the thermal front retains and concentrates $S$. aurita larvae, and could represent one of the limiting factors for the expansion of the species towards the north.
\end{abstract}

KEY WORDS: Sardinella aurita $\cdot$ Spawning $\cdot$ Eggs $\cdot$ Larvae $\cdot$ Circulation $\cdot$ Retention $\cdot$ Northwestern Mediterranean

Resale or republication not permitted without written consent of the publisher

\section{INTRODUCTION}

During recent years, a number of studies have documented important changes in marine ecosystems in association with long-term changes observed in climatic and oceanographic records (e.g. Beaugrand \& Reid 2003, Perry et al. 2005). The Mediterranean Sea, located in the temperate zone of the northern hemisphere, is a unique marine region, surrounded almost completely by land and connecting 3 continents. Its long geological history, as well as the variety of climatic and hydrological conditions, has resulted in relatively high biodiversity. Species of subtropical origin are found mainly in the eastern basin and southern Mediterranean (Bianchi \& Morri 2000), where the surface water temperature is higher than average (Theo- charis et al. 1993). Cold-temperate species inhabit the northern areas - the Gulf of Lions, Ligurian Sea and northern Adriatic (Bianchi \& Morri 2000) — where the water temperature is colder, with a seasonal variation at the surface ranging from less than 12 to more than $25^{\circ} \mathrm{C}$ (Salat 1996, Gačić et al. 1997). Nevertheless, physical and biological changes have been documented in recent years as a response to climate forcing. Evidence of a significant increase in temperature has been recorded for deep (Bethoux et al. 1990, Rixen et al. 2005), intermediate and surface waters (VargasYáñez et al. 2005). In addition, there is evidence that the distribution range of fishes and benthic organisms characteristic of warm waters has expanded, and that their presence is more frequent in the colder, northern sector (e.g. Francour et al. 1994, Bianchi \& Morri 2000). 
Round sardinella Sardinella aurita is a thermophilic small pelagic species that inhabits the tropical and subtropical waters of the western and eastern Atlantic Ocean, the Pacific Ocean, the Mediterranean and, occasionally, the Black Sea (Bauchot 1987). Traditionally, in the Mediterranean, the species was particularly abundant in the warm waters of the eastern and southwestern basins (Ben-Tuvia 1960a). Recently, however, an increasing abundance and gradual northward expansion of $S$. aurita has been reported along western Mediterranean coasts in relation to the progressive warming reported in the basin (Sabatés et al. 2006). Furthermore, Sabatés et al. (2006) have documented the successful reproduction of the species close to the edge of its range, confirming its establishment in the new distribution areas.

In the northwestern Mediterranean, the most abundant species of small pelagic fish are the European sardine Sardina pilchardus and anchovy Engraulis encrasicolus (Lleonart \& Maynou 2003). These 2 dominant species have non-overlapping spawning periods, autumn-winter and spring-summer, respectively (Palomera et al. 2007). Their eggs and larvae dominate the ichthyoplanktonic fraction in neritic areas of the northwestern Mediterranean coasts during these periods. The reproductive period of round sardinella is relatively short and occurs in summer, during the same season as the anchovy, from the end of June to September, when the sea surface temperature reaches the highest values of the year (Palomera \& Sabatés 1990, Somarakis et al. 2002, Tsikliras \& Antonopoulou 2006).

The summer period in the Mediterranean is characterized by a stratified water column with a strong thermocline located between 15 and $40 \mathrm{~m}$. Surface productivity is restricted to areas under the influence of runoff waters from local rivers. These waters tend to spread above the thermocline, supplying nutrients to the typically depleted surface waters (Salat et al. 2002). The general surface circulation in the northwestern Mediterranean region is well established with a main shelfslope current, the Northern Current, along the whole northern continental slope (Millot, 1999). This current flows southwestwards along the Catalan coast at approximately $30 \mathrm{~cm} \mathrm{~s}^{-1}$ at the surface (Castellón et al. 1990). The Northern Current shows high mesoscale variability which plays a decisive role in exchange processes between shelf and oceanic waters associated with instabilities (Wang et al. 1988) or oscillations of the current (Sabatés et al. 2004). Other features such as the presence of anticyclonic eddies over the continental shelf and slope have also been described as associated with this mesoscale activity (Rojas et al. 1995, Flexas et al. 2002). Rubio et al. (2005) suggested that these eddies were generated by the direct effect of wind curl, either locally or advected by the current from the Gulf of
Lions, where winds are stronger and more frequent. These winds are also responsible for a marked thermal front perpendicular to the coast, between 41 and $42^{\circ} \mathrm{N}$ that has been frequently depicted by satellite images (López-García et al. 1994). The front is generated by the differences in depth of the upper mixed layers on its northern and southern sides. The water column on the northern side has a cooler and deeper mixed layer through intense wind mixing that is reflected by a lower temperature at the surface. This front is thus associated with the southern limit of the strong northwesterly winds (López-García et al. 1994).

In the light of the northward expansion and increasing abundance of Sardinella aurita in the northwestern Mediterranean, the present study analyzes the spatiotemporal distribution of $S$. aurita spawning (in 20032004) at the northern limit of its geographic distribution in relation to the environmental parameters during that period. The objective was to characterize the spawning habitat of $S$. aurita in the area and to determine what environmental and hydrodynamic conditions may control the northward expansion of the species in the western Mediterranean.

\section{MATERIALS AND METHODS}

Physical and biological sampling was conducted on the continental shelf and slope along the Catalan coast (northwestern Mediterranean) during 4 oceanographic surveys centred on the reproductive period of Sardinella aurita in the western Mediterranean (Palomera \& Sabatés 1990): 18 to 25 July and 11 to 20 September 2003; and 23 June to 1 July and 21 to 29 July 2004. In each survey, 66 sampling stations were set up on transects perpendicular to the shoreline, starting in nearshore waters and extending out to the slope. On each transect, stations were placed 7.5 nautical miles apart and the distance between transects was 10 nautical miles (Fig. 1).

Vertical profiles of 3 basic hydrographic variables (temperature, salinity and fluorescence) were obtained with a Neil Brown Mark III-CTD (WOCE standard) equipped with a Sea-Tech fluorometer. The vertical profiles were interpolated to $1 \mathrm{~m}$ depth intervals. In addition, an acoustic Doppler current profiler (ADCP) recorded at 5 min intervals along the ship's course, but only few records were reliable $(<40 \%)$ due to technical problems (e.g. noise, ship velocity changes). Geostrophic fields were obtained from the dynamic heights calculated with a reference level of $600 \mathrm{~m}$ and, where depth was lower, were extrapolated using the continuity equation applied to the deepest level of 3-station clusters (cf. Hidaka 1940). This type of extrapolation to lower depths may introduce errors in the current esti- 


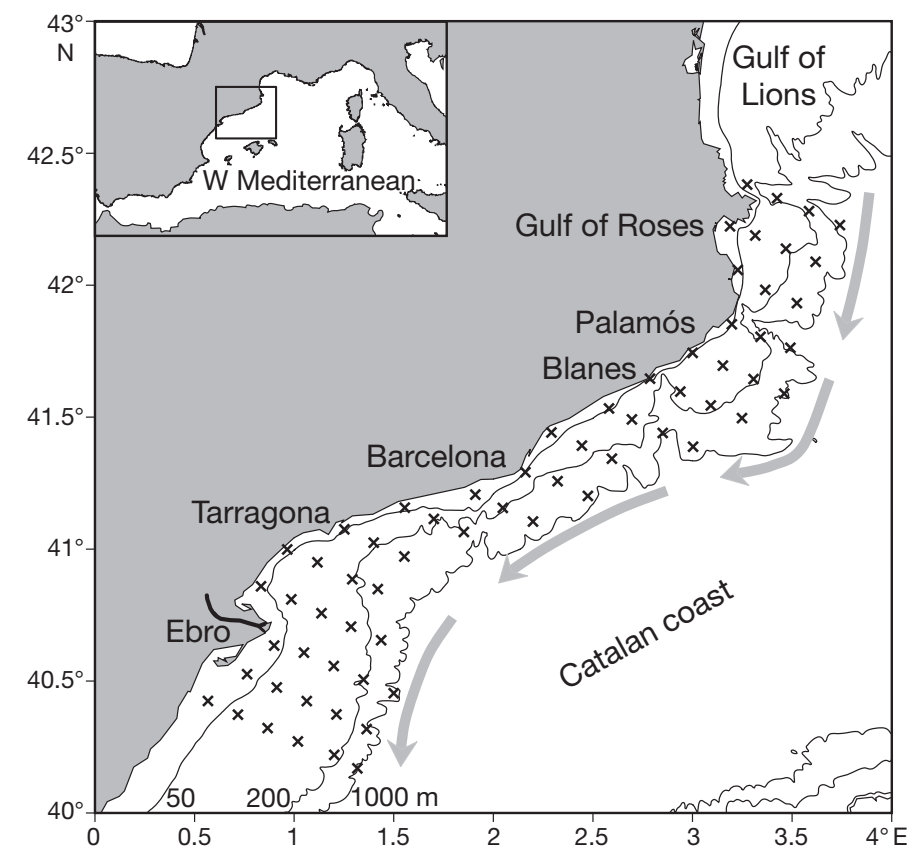

Fig. 1. Study area on the Catalan coast, Spain, showing sampling stations (x). The isobaths shown are 50, 200 and $1000 \mathrm{~m}$. Arrows indicate the typical path of the Northern Current

mates on wide shelves since the number of steps required increases with shelf width. Therefore, to avoid errors, no emphasis was placed on the current patterns in the shallower zones of the large shelves, such as the Ebro shelf. In other cases, if available, a comparison with ADCP data was used to confirm the trends of the extrapolated geostrophic circulation over narrower shelves.

At each station, water samples for chlorophyll a (chl a) determinations were collected using a rosette system at 3 depths down to $70 \mathrm{~m}$, throughout the day and night, in order to calibrate the fluorometer. Chl a concentration ( $\mu \mathrm{g} \mathrm{l}^{-1}$ ) was determined fluorometrically (Yentsch \& Menzel 1963) on board. Water samples of 100 to $200 \mathrm{ml}$ were filtered through Whatman GF/F filters. Chl a was extracted from filters immersed in $6 \mathrm{ml}$ of $90 \%$ acetone $\left(24 \mathrm{~h}\right.$ at $4^{\circ} \mathrm{C}$ in darkness). The extract was analysed with a Turner Designs fluorometer calibrated with pure chl a (Sigma). The relationship between chl a concentration and fluorescence (flu) obtained from each cruise was used to convert the continuous CTD fluorescence register into chl a concentration. Calibrations were similar on cruises performed the same year: chl $a=1.69$ flu +0.0001 (July 2003); chl $a=1.62$ flu -0.0222 (September 2003); chl $a=2.14 \mathrm{flu}-0.0341$ (June 2004); and chl $a=2.04 \mathrm{flu}$ -0.0223 (July 2004). To present an index of chl a for the upper mixed layer $(\sim 20 \mathrm{~m})$, vertical values were averaged across the 0 to $20 \mathrm{~m}$ depth interval. Given the variability and patchiness of this variable, the inte- grated value should be more robust than the value for a single layer.

Fish larvae were sampled by means of oblique tows, from a maximum depth of $200 \mathrm{~m}$ to the surface, using a Bongo net with a $60 \mathrm{~cm}$ diameter opening and a mesh size of $300 \mu \mathrm{m}$. The volume of filtered water was estimated by means of a flow meter placed in the centre of the net mouth. Zooplankton samples were fixed in $5 \%$ formaldehyde buffered with sodium tetraborate.

In the laboratory, fish eggs and larvae were sorted and identified from the preserved samples. The number of Sardinella aurita eggs and larvae collected at each station was standardized to number per $10 \mathrm{~m}^{2}$ of the sea surface.

Contour maps of sea surface temperature, salinity and mean chl a were obtained using Ocean Data View software (Schlitzer 2004). For geostrophic fields, a minimum curvature algorithm (cf. Briggs 1974) was used.

In order to assess the preferred ranges of environmental variables for Sardinella aurita eggs and larvae, a quotient-rule analysis was applied (van der Lingen et al. 2001, Twatwa et al. 2005). Each environmental variable was divided into a number of categories $(c)$, to ensure that the maximum occurrence per category did not exceed $25 \%$ of all measurements. Using their frequency of occurrence ( $\%$ environmental variable) and the percentage of total egg and larvae abundances (\% S. aurita) per category, the quotient $(Q)$ was calculated as:

$$
Q(c)=\frac{\% S \text {. aurita }(C)}{\% \text { environmental variable }(c)}
$$

so that $Q(c)>1$ indicates an apparent selection for a specific environmental variable range (category).

\section{RESULTS}

\section{Hydrography}

In all cruises, the horizontal temperature distributions together with the mean geostrophic circulation at $21 \mathrm{~m}$ (Fig. 2) showed the presence of the Northern Current near the shelf break in the northern part of the sampled region. North of Barcelona, a thermal front, with higher temperatures on its southern side, was evident across the shelf. Its orientation, gradient and position varied between cruises. The presence of some anticyclonic eddies was also a common feature in all the cruises.

The sea surface temperature in the study area was highest in July 2003 (Fig. 2), 2 to $4^{\circ} \mathrm{C}$ higher than on the other cruises (Table 1). The thermal front was located near Blanes, and was directed towards the SSE with a temperature difference of almost $2^{\circ} \mathrm{C}$. A double anticyclonic eddy system was located in the central 


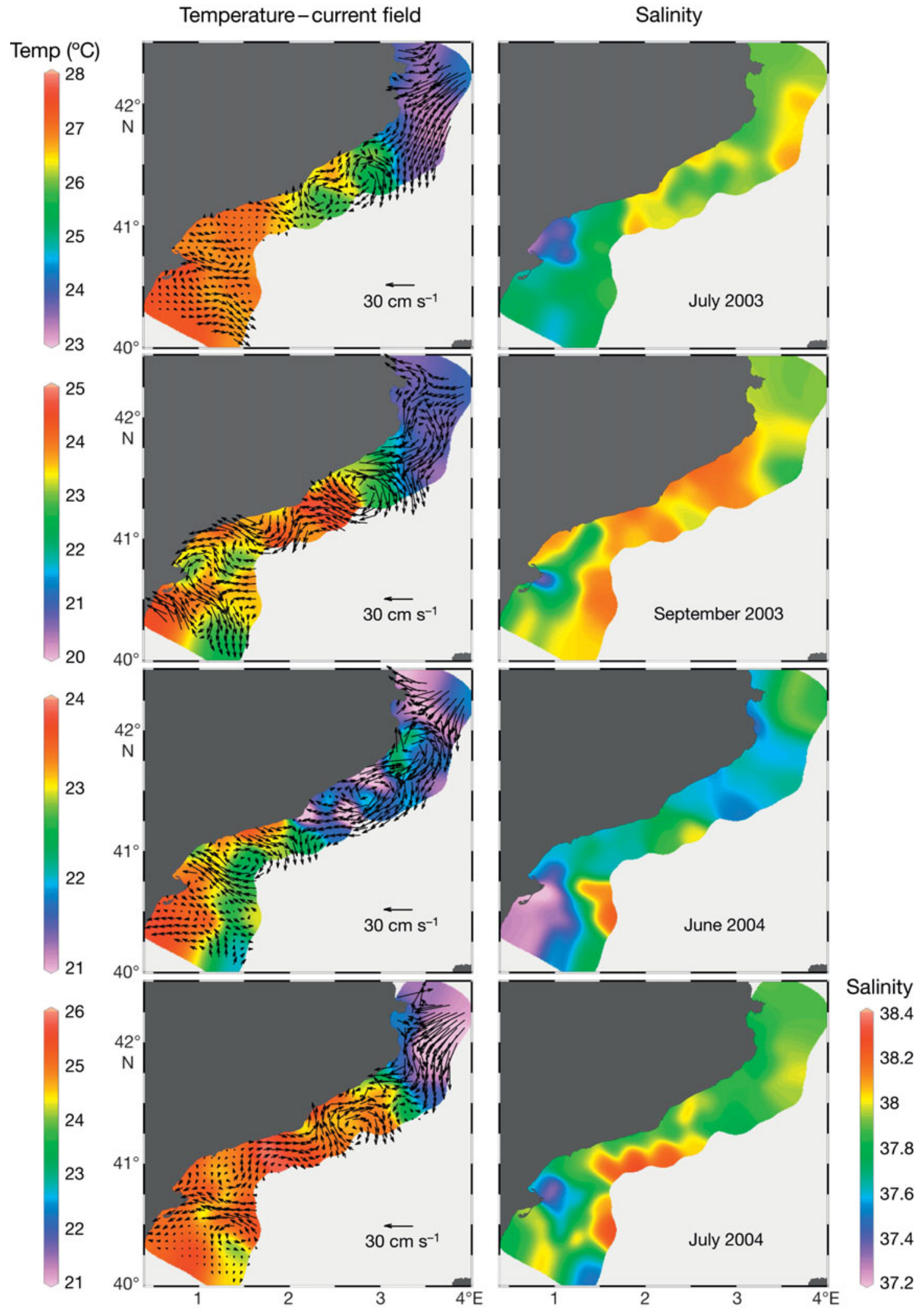

Fig. 2. Geostrophic current fields at $21 \mathrm{~m}$ depth, relative to $600 \mathrm{~m}$, overlaid on maps of surface (5 m) temperature (left panels) and salinity (right panels) during the 4 cruises. Note that the scales of temperature are adapted to the different temperature ranges of each cruise (see Table 1) 
Table 1. Sardinella aurita. Mean $( \pm \mathrm{SD})$ and range of sea surface (5 $\mathrm{m}$ depth) temperature $\left({ }^{\circ} \mathrm{C}\right)$ and salinity, and mean $( \pm \mathrm{SD})$ abundance $\left(\right.$ no. $\left.10 \mathrm{~m}^{-2}\right)$ of $S$. aurita eggs and larvae. (-) no data available

\begin{tabular}{|lcccc|}
\hline Date & Temperature & Salinity & S. aurita eggs & S. aurita larvae \\
\hline Jul 2003 & $25.8 \pm 1.5$ & $37.82 \pm 0.18$ & $212 \pm 392$ & $162 \pm 283$ \\
& $(23.1-27.6)$ & $(37.26-38.09)$ & & $31 \pm 37$ \\
Sep 2003 & $22.8 \pm 1.3$ & $37.99 \pm 0.16$ & - & $452 \pm 966$ \\
& $(20.4-24.8)$ & $(37.22-38.19)$ & & $606 \pm 826$ \\
Jun 2004 & $22.3 \pm 1.0$ & $37.61 \pm 0.22$ & $301 \pm 342$ & \\
& $(20.3-23.8)$ & $(37.16-38.21)$ & & \\
Jul 2004 & $24.1 \pm 1.6$ & $37.86 \pm 0.19$ & $461 \pm 873$ & \\
& $(20.1-26.0)$ & $(37.16-38.28)$ & & \\
\hline
\end{tabular}

part of the studied area, with the eastern eddy being larger and centred near the shelf break. On the northern side of this eddy, the current formed a large meander with a coastal intrusion just over the thermal front. The Northern Current was then deflected towards the open sea, out of the sampling area, following the thermal front. A meandering coastal current flowed from near Tarragona, at the northern limit of the Ebro shelf, towards the north, contouring the double eddy system until it reached the thermal front where it converged with the Northern Current.

In September 2003 (Fig. 2), the sea surface temperature was in general much lower than in July (Table 1). The thermal front was located roughly at the same position and in the same orientation as during the previous cruise. A large anticyclonic eddy was also located just to the western side of the thermal front. No traces of any coastal current were evident south of the thermal front.

In June 2004 (Fig. 2), the sea surface temperature was the lowest of the 4 cruises (Table 1). During this survey, the main thermal front was evident south of the Gulf of Roses, directed towards the east with a temperature difference of nearly $1^{\circ} \mathrm{C}$ between both sides of the front. A secondary surface temperature front was located west of Barcelona. On this cruise, 3 anticyclonic eddies were detected: east of Palamós, northeast of Barcelona and off Tarragona. In the northern limit of the sampled area, the Northern Current appeared deflected towards the shelf, suggesting an intrusion of slope waters. A coastal current flowed towards the north from near Barcelona to the main thermal front, converging there with the Northern Current. As in July 2003, this coastal current contoured the 2 eddies with a meandering path.

In July 2004 (Fig. 2), the sea surface temperature distribution was similar but with lower values than in July 2003 (Table 1), and the thermal front, oriented towards the southeast, was wider, i.e. with a similar temperature difference but a lower gradient. A large anticyclonic eddy was located east of Barcelona, and the thermal front coincided with the northern edge of this eddy. The Northern Current flowed along the shelf break in the northern part of the area with a meandering pattern and a clear intrusion towards the coast north of Palamós. As in July 2003, from this point the current was deflected towards the open sea, out of the sampled area, at the thermal front position. A coastal current towards the north also flowed from near Tarragona to the position of the thermal front, where it converged with the Northern Current.

The most notable feature of the horizontal surface salinity distributions (Fig. 2) was the presence of low salinity patches on the Ebro River continental shelf, in the southern half of the sampled area. In July 2003, 2 low salinity patches were detected: one close to the coast on the northern side of the Ebro delta, and the other near the shelf edge at the southern limit of the sampled area. In September 2003, surface salinity was higher than in July (Table 1). Only a single low salinity patch, smaller than those found during the previous cruise, was detected at the tip of the Ebro delta. By contrast, in June 2004 surface salinity values were generally the lowest. A low salinity $(<37.4)$ patch covering a large area on the southern half of the Ebro continental shelf was observed. The surface salinity distribution found during the last cruise, in July 2004, showed average values similar to those found in July 2003 (Table 1). There were also 2 low salinity patches: one at the tip of the Ebro delta spreading towards the northeast, and another at the shelf edge on the southern limit of the sampled area.

Mean surface chl a distributions (Fig. 3) showed very low values almost everywhere in the area for all cruises. There were, however, some patches of relatively high surface chl a near the Ebro delta $\left(>0.5 \mu \mathrm{g} \mathrm{l}^{-1}\right)$, whose position agreed with the low surface salinity patches described previously. Some other small patches were also observed very close to the coast in the central part of the study area in the vicinity of Barcelona, which is a zone with high population density and secondary river mouths.

\section{Sardinella aurita eggs and larvae}

Abundance of Sardinella aurita eggs and larvae was higher in 2004 compared to 2003. The highest concentrations were detected in July 2004 and the lowest in September 2003, coinciding with the end of the species' spawning season (Table 1). On all the cruises, the main spawning areas were located in the southern half of the study area, close to the coast. In the northern 


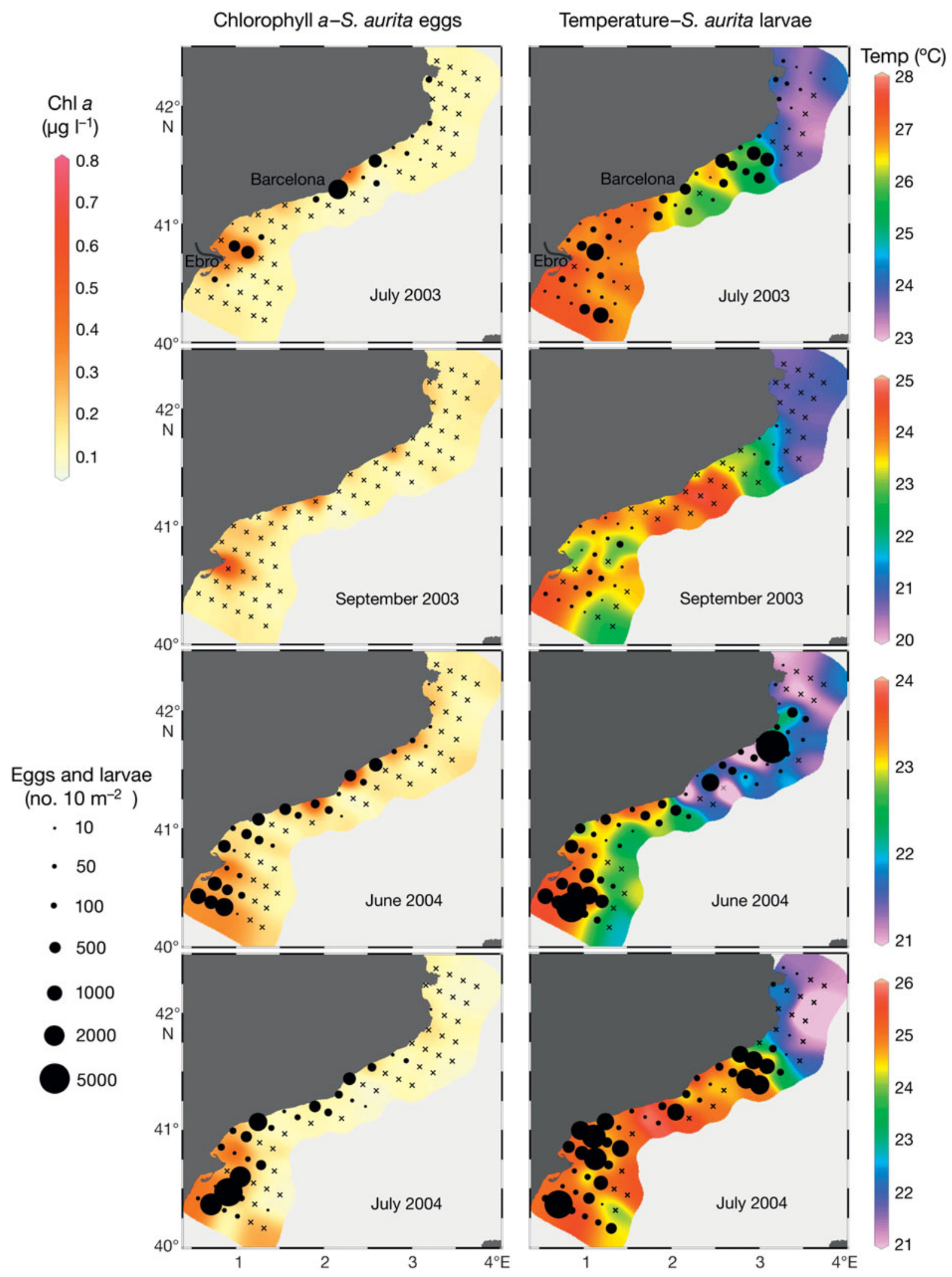

Fig. 3. Sardinella aurita. Distribution of eggs overlaid on maps of mean surface chlorophyll a (upper $20 \mathrm{~m}$ ) (left panels) and distribution of larvae overlaid on maps of sea surface temperature (right panels) during 4 cruises. (x) sampling stations 
half, spawning was limited to the coastal stations, and eggs were almost absent beyond the thermal front (Fig. 3). The highest egg concentrations were detected in areas of high surface chl a: on the Ebro continental shelf in low salinity patches, and in the coastal area near Barcelona.

Quotient analysis with respect to bathymetry showed that spawning took place in areas where depth was less than 100 m (Fig. 4). Sardinella aurita spawning was also associated with high temperatures, between 23 and $26.5^{\circ} \mathrm{C}$, with the highest numbers of spawned eggs at $25.5^{\circ} \mathrm{C}$. Spawning also appeared to
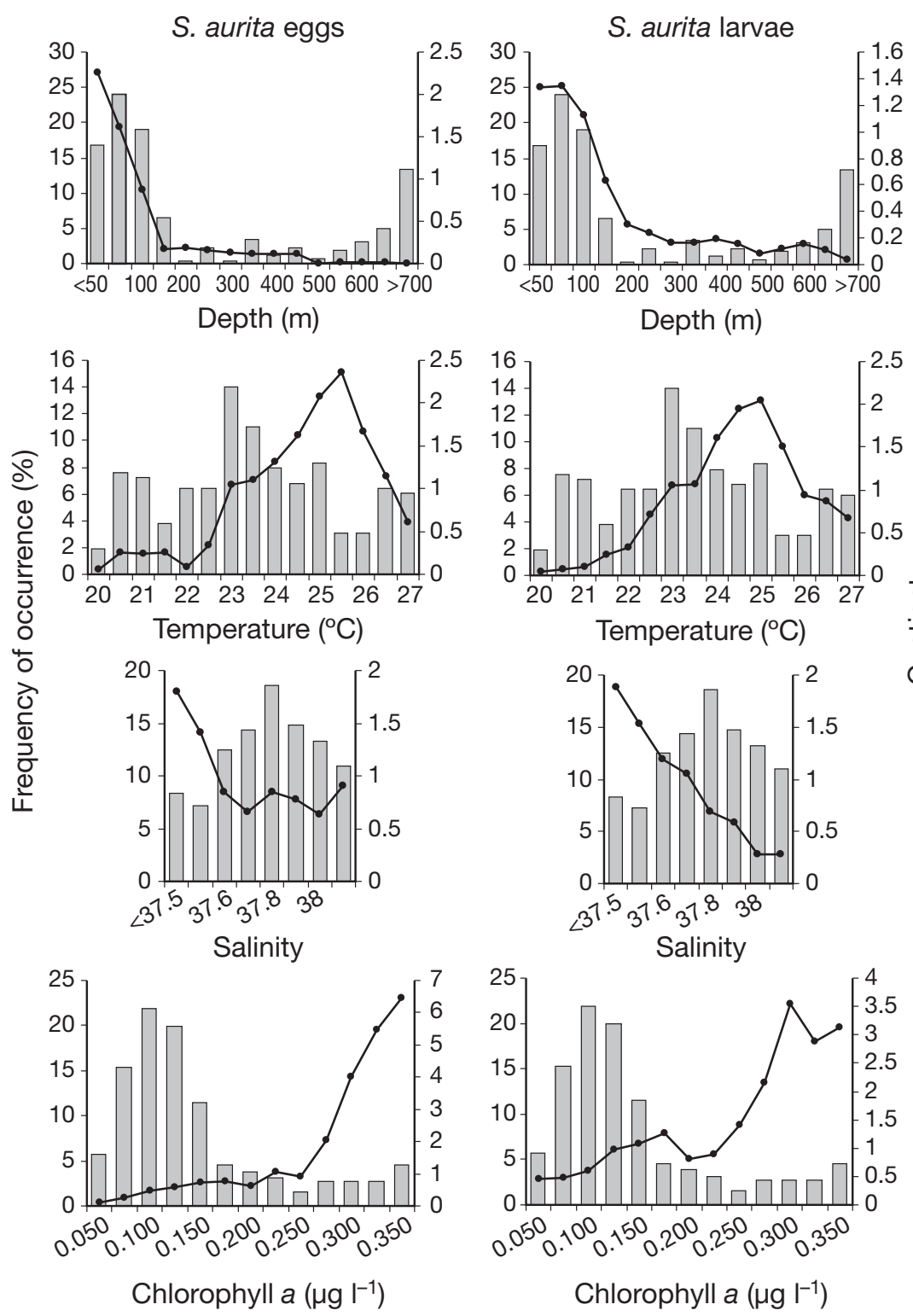

Fig. 4. Sardinella aurita. Quotient rule analysis showing the frequency of occurrence of environmental variables (surface [5 $\mathrm{m}]$ temperature, salinity and mean chlorophyll a [upper $20 \mathrm{~m}$ ]) and $S$. aurita egg and larval abundance/ environmental variable quotient curves be related to low salinity $(<37.5)$ and high surface chl $a$ $\left(>0.27 \mu \mathrm{g} \mathrm{l}^{-1}\right)$.

The spatial distribution of Sardinella aurita larvae covered an area wider than the eggs and extended further offshore (Fig. 3). In general, larvae were found all along the continental shelf, but were especially abundant in the southern part of the study area, associated with patches of low salinity surface waters from the Ebro River runoff, where surface chl a values were also high (Figs. $2 \& 3$ ). Larval distribution to the north did not extend beyond the thermal front. In addition, relatively large concentrations of larvae were found on the southern side of the front. This was particularly evident in both July 2003 and 2004, while in June 2004 high concentrations were slightly displaced to the south, approximately between the 2 eddies described above (Fig. 3). In September 2003, the abundance of larvae was very low, coinciding with the end of the reproductive period (Fig. 3).

Quotient analysis with respect to bathymetry showed that Sardinella aurita larvae were mainly located at stations less than $150 \mathrm{~m}$ in depth (Fig. 4). Larvae were associated with a range of temperatures slightly narrower than that observed for the eggs, between 24 and $25.5^{\circ} \mathrm{C}$ (Fig. 4). Larval abundance also appeared to be related to low salinity $(<37.6)$ and high surface

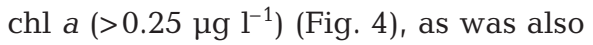
found for the eggs.

\section{DISCUSSION}

The spatiotemporal scale of the samplings allowed the environmental conditions of Sardinella aurita spawning to be characterized at the northern edge of their geographic distribution range. On average, the spatial patterns were similar between cruises. A clear preference for spawning in coastal areas shallower than $100 \mathrm{~m}$ was determined; however, larvae showed a wider distribution, extending offshore up to the position of the $150 \mathrm{~m}$ isobath. These observations are consistent with those reported by Palomera \& Sabatés (1990) for the same area.

Sardinella aurita eggs and larvae showed a clear association with relatively low salinity and high surface chl a 
(Fig. 4). These conditions, together with high concentrations of eggs and larvae, were found near the coast, especially in the southern half of the study area over the wide shelf in front of the Ebro River mouth (Fig. 3). The high surface productivity on the Ebro shelf is characteristic of this area (Salat et al. 2002), and high concentrations of zooplankton at the surface have been reported as associated with these waters of continental origin (Sabatés et al. 2008). On the western coast of Africa, where $S$. aurita is abundant, the reproduction of the species occurs during periods of high productivity associated with seasonal upwelling (Quaatey \& Maravelias, 1999, Ettahiri et al. 2003, Zeeberg et al. 2008). In this region, the reported optimal salinity for spawning ranged between 35.5 and 36.7 (Conand 1977, Ettahiri et al. 2003). In general, the salinity in the Mediterranean is higher than in the Atlantic, except in the Alboran Sea and, occasionally, under the influence of heavy runoff. The results of the present study suggest that salinities higher than the values stipulated by Conand (1977) and Ettahiri et al. (2003) do not seem to seriously affect spawning. However, the high abundances of eggs and larvae found in at low salinities $(<37.6)$ indicates a preference for the lower range of the typical western Mediterranean salinities (36.8 to 38.4). Given that the values from the present study are still at least 1 salinity unit higher than those reported for the western coast of Africa, and that the results show a clear association of eggs and larvae with low salinity and relatively high surface chl $a$, this preference must be related more to surface productivity than to salinity itself.

In the Mediterranean, the summer period, when Sardinella aurita reproduces, is characterized by a stratified water column with a marked thermocline. Consequently, vertical water movement is very limited and almost all the surface nutrients are depleted. Primary production remains limited to a deep chlorophyll maximum (DCM), a thin layer at the deepest levels of the photic zone (Estrada 1985), where there is a compromise between nutrient concentration and light intensity (Estrada et al. 1993). The only nutrient contribution to the surface during the fully stratified season comes from riverine runoff water (Blanc et al. 1969) which allows surface productivity to be maintained in small areas under the direct influence of river discharges. Eggs and early developmental stages of $S$. aurita larvae are located close to the surface, above the thermocline (Sabatés et al. 2008). From $8 \mathrm{~mm}$ in standard length onwards, larvae migrate to deeper levels during the day for feeding, although they do not reach the depths ( $\sim 50 \mathrm{~m})$ where the DCM and the high concentrations of microzooplankton, their main food, occur (Sabatés et al. 2008). Sabatés et al. (2008) suggested that $S$. aurita larvae would have difficulties reaching DCM since the temperature at these depths $\left(\sim 15^{\circ} \mathrm{C}\right)$ may be too low considering the thermophilic character of the species (Ben Tuvia 1960a). This is a constraint to obtaining food in the areas where surface primary production is limited. Thus, the Ebro shelf, where high surface production levels have been detected under the influence of the Ebro River runoff, would constitute a favorable habitat for the development and survival of $S$. aurita larvae.

It is known that temperature affects the reproductive biology of Sardinella aurita. Thus, not only does the onset of the reproductive season seem to happen earlier in warmer years (Ben-Tuvia 1960b, Tsikliras \& Antonopoulou 2006), but the duration of spawning is also more extensive in the southern, warmer parts of the Mediterranean Sea than in the northern, colder parts (Palomera \& Sabatés 1990, Tsikliras \& Antonopoulou 2006). In the present study, larvae of $S$. aurita were found on all the cruises; however in September there were no eggs, likely due to the end of the spawning season at this time. Results from quotient analysis indicate that the range of temperatures in which eggs and larvae appeared was between 20 and $27^{\circ} \mathrm{C}$, although the maximum intensity of spawning took place between 23 and $26.5^{\circ} \mathrm{C}$ (Fig. 4). Previous studies conducted in the northwestern Mediterranean indicated that the spawning of this species took place at temperatures higher than $23^{\circ} \mathrm{C}$ (Navarro 1932, Andreu \& Rodriguez-Roda 1951, Palomera \& Sabatés 1990). In the northeastern Mediterranean, the presence of larvae in the plankton also occurred from June to September (Somarakis et al. 2002, Koutrakis et al. 2004) at temperatures ranging between 21.8 and $24.1^{\circ} \mathrm{C}$, slightly lower than that defined in the present study. The spatial distribution of eggs and larvae (Fig. 3) showed that they were absent north of the thermal front, independently of its position. This would suggest that temperature beyond the front was too low for spawning. However, in June 2004 the temperature south of the thermal front, where larvae were abundant, was lower than that recorded north of the front in July both years. This observation and the abovementioned results from quotient analysis show that sea surface temperatures north of the front were not low enough to be a limiting factor in reproduction. Moreover, in upwelling regions of the eastern Atlantic Ocean, spawning has been reported at temperatures ranging between 21.6 and $26.5^{\circ} \mathrm{C}$ on the coast of Ghana (Conand 1977, Quaatey \& Maravelias 1999) and 18 to $21.1^{\circ} \mathrm{C}$ off the Western Sahara (Ettahiri et al. 2003). Temperature values detected in the present study are clearly higher than those reported in the above-mentioned areas, where this species is abundant. Hence, all the above considerations indicate that the absence of larvae on the northern side of the thermal front is not due to temperature itself and may be related to the mesoscale dynamics.

The mesoscale dynamics associated with the thermal front across the shelf in the northern half of the sam- 
pled area are evident, overlying the circulation on the temperature distribution (Fig. 2). In all surveys, the northern side of the front is under the direct influence of the Northern Current, advecting slope water from the north, while its southern side is dominated by coastal water. The front is always associated with the northeastern flank of an anticyclonic eddy, centred on the slope. This eddy deflects both the Northern Current and the more or less fragmented coastal northward current towards the open sea. Therefore, this convergence of coastal and slope waters and the association of the thermal front with an eddy could help to maintain the thermal gradient long after the onset of the wind (e.g. Pascual et al. 2002). The observed variability in the northward extension of larvae among cruises thus depends on the position of the front and its associated eddy. This variability could be related to the southwards advection of anticyclonic eddies in the northern sector off the Catalan coast (Arnau et al. 2004, Rubio et al. 2005).

In all the samplings performed, the intrusion of the Northern Current towards the shelf, north of the thermal front, marks the northern limit of Sardinella aurita egg and larvae distribution, independent of temperature values or the position of the front. In addition, larvae tended to concentrate near the convergence associated with the front. These larvae could be transported northwards from coastal spawning areas by the coastal current until the convergence. In this situation, some of the larvae could be trapped by the eddy associated with the thermal front. The virtual absence of eggs and larvae to the north of this front indicates that spawning is very limited in this area. This is not only related to the low abundance of adults in the northern part of the Catalan coast (Sabatés et al. 2006), but also to the intrusion of the Northern Current. If there was spawning of $S$. aurita further north on the Catalan coast and in the Gulf of Lions, near the mouth of the Rhone River, larvae would probably be transported by the Northern Current, as has been described for anchovy larvae in the same area (Sabatés et al. 2007). The total absence of larvae in the waters transported by the Northern Current should support the evidence of the absence of spawning in the Gulf of Lions, even during hot summers such as 2003. Considering that, from the point of view of surface productivity, the environmental characteristics of the shelf of the Gulf of Lions are similar to those of the Ebro shelf, the absence of spawning in this area suggests that the expansion of this species towards the north has not yet led to colonization of the area. Therefore, the thermal front tied to the intrusions of the Northern Current retains and concentrates $S$. aurita larvae, although, at the same time it could represent one of the limiting factors for the expansion of the species towards the north, preventing the colonization of the Gulf of Lions shelf, as has happened with the Ebro. Another limiting factor in the expansion of $S$. aurita, as indicated by Sabatés et al. (2008), is the difficulty larvae would experience in obtaining food in the deep productive levels.

In summary, there are 2 critical summer environmental factors for reproduction and expansion of round sardinella in the western Mediterranean along the Catalan coast. In the south, the inflow of low saline and productive surface water from the River Ebro runoff offers favourable conditions for spawning and larval survival. However, northwards the mesoscale dynamics with a persistent thermal front associated with an intrusion of the Northern Current towards the shelf would act as a limiting factor for the expansion of the species towards the north.

Acknowledgements. We greatly appreciate the assistance of the crew of the RV 'García del Cid' and all the participants during the CACO cruises. M.E. was partially funded by contracts 2005SGR00476 and ESP2005-06823-C05-01. This work was supported by the project REN 2002-01339/MAR.

\section{LITERATURE CITED}

Andreu B, Rodriguez-Roda J (1951) Estudio comparativo del ciclo sexual, engrasamiento y repleción estomacal de la sardina, alacha y anchoa del mar Catalán, acompañado de relación de pescas de huevos planctónicos de estas especies. Publ Inst Biol Apl 9:193-232

Arnau P, Liquete C, Canals M (2004) River mouth plume events and their dispersal in the northwestern Mediterranean Sea. Oceanography 17:22-31

Bauchot ML (1987) Poissons osseux. In: Fischer W, Bauchot ML, Schneider M (eds) Fiches FAO d'identification pour les besoins de la pêche. Méditerranée et mer Noire. Zone de pêche 37, Vol 2. Commission des Communautés Européennes and FAO, Rome, p 891-1421

Beaugrand G, Reid PC (2003) Long-term changes in phytoplankton, zooplankton and salmon related to climate. Glob Change Biol 9:801-817

Ben-Tuvia A (1960a) Synopsis of biological data on Sardinella aurita of the Mediterranean Sea and other waters. FAO Fish Synop 14:287-312

Ben-Tuvia A (1960b) Fluctuations in the stock of Sardinella aurita and its dependence on temperature and rain. In: Rosa H Jr, Murphy GI (eds) Proceedings of the world scientific meeting on the biology of sardines and related species, Vol 3. FAO, Rome, p 1193-1203

> Bethoux JP, Gentili B, Raunet J, Tailliez D (1990) Warming trend in the western Mediterranean deep water. Nature 347:660-662

> Bianchi CN, Morri C (2000) Marine biodiversity of the Mediterranean Sea: situation, problems and prospects for future research. Mar Pollut Bull 40:367-376

Blanc F, Leveau M, Szekielda KH (1969) Effets eutrophiques au débouché d'un grand fleuve (Grand Rhône). Mar Biol 3:233-242 (with English Abstract)

Briggs IC (1974) Machine contouring using minimum curvature. Geophysics 39:39-48

Castellón A, Font J, García E (1990) The Liguro-ProvençalCatalan Current (NW Mediterranean) observed by Doppler profiling in the Balearic Sea. Sci Mar 54:269-272 
Conand F (1977) Eggs and larvae of the gilt sardine (Sardinella aurita) of Senegal: distribution, growth, mortality, abundance variations from 1971 to 1976. Cah Oceanogr 15:201-214

Estrada M (1985) Deep phytoplankton and chlorophyll maxima in the Western Mediterranean. In: Moraitou-Apostolopoulou M, Kortsis V (eds) Mediterranean marine ecosystems. Plenum Press, New York, p 247-277

Estrada M, Marrasé C, Latasa M, Berdalet E, Delgado M, Riera T (1993) Variability of deep chorophyll maximum characteristics in the Northwestern Mediterranean. Mar Ecol Prog Ser 92:289-300

Ettahiri O, Berraho AM, Vidy G, Ramdani M, Do chi T (2003) Observation on the spawning of Sardina and Sardinella off the south Moroccan Atlantic coast $\left(21-26^{\circ} \mathrm{N}\right)$. Fish Res 60:207-222

Flexas MM, De Madron XD, Garcia MA, Canals M, Arnau P (2002) Flow variability in the Gulf of Lions during the MATER HFF experiment (March-May 1997). J Mar Syst 33-34:197-214

> Francour P, Boudouresque CF, Harmelin JG, HarmelinVivien ML, Quignard JP (1994) Are the Mediterranean waters becoming warmer? Information from biological indicators. Mar Pollut Bull 28:523-526.

> Gačić M, Marullo S, Santoleri R, Bergamasco A (1997) Analysis of the seasonal and interannual variability of the sea surface temperature field in the Adriatic Sea from AVHRR data (1984-1992). J Geophys Res C 102:22937-22946

Hidaka K (1940) Absolute evaluation of oceanic currents in dynamic calculations. Proc Imp Acad Tokyo 16:391-393

Koutrakis ET, Kallianiotis AA, Tsikliras AC (2004) Temporal patterns of larval fish distribution and abundance in a coastal area of northern Greece. Sci Mar 68:585-595

Lleonart J, Maynou F (2003) Fish stock assessments in the Mediterranean: state of the art. Sci Mar 67(Suppl):37-49

López-García MJ, Millot C, Font J, García-Ladona E (1994) Surface circulation variability in the Balearic Basin. J Geophys Res C 99:3285-3296

Millot C (1999) Circulation in the western Mediterranean sea. J Mar Syst 20:423-442

Navarro FP (1932) Nuevos estudios sobre la alacha (Sardinella aurita C.V.). Notas Inst Esp Oceanogr 2:1-35

Palomera I, Sabatés A (1990) Co-occurrence of Engraulis encrasicolus and Sardinella aurita eggs and larvae in the western Mediterranean. Sci Mar 54:51-67

> Palomera I, Olivar MP, Salat J, Sabatés A, Coll M, García A, Morales-Nin B (2007) Small pelagic fish in the NW Mediterranean Sea: an ecological review. Prog Oceanogr 74: 377-396

Pascual A, Buongiorno Nardelli B, Larnicol G, Emelianov M, Gomis D (2002) A case of an intense anticyclonic eddy in the Balearic Sea (western Mediterranean). J Geophys Res C 107:3183, doi:10.1029/2001JC000913

Perry AL, Low PJ, Ellis JR, Reynolds JD (2005) Climate change and distribution shifts in marine fishes. Science 308: 1912-1915 Medline.

> Quaatey SNK, Maravelias CD (1999) Maturity and spawning pattern of Sardinella aurita in relation to water temperature and zooplankton abundance off Ghana, West Africa. J Appl Ichthyol 15:63-69

Rixen M, Beckers JM, Levitus S, Antonov J and others (2005) The Western Mediterranean Deep Water: a proxy for climate change. Geophys Res Lett 32:L12608, doi:10.1029/ 2005GL022702

Rojas P, García MA, Sospedra J, Figa J and others (1995) Summer modification of the flow structure on the Blanes canyon (NW Mediterranean). Oceanol Acta 18:443-454
Rubio A, Arnau PA, Espino M, Flexas MM, Jordà G, Salat J, Puigdefàbregas J, Sánchez-Arcilla A (2005) A field study of the behaviour of an anticyclonic eddy on the Catalan continental shelf (NW Mediterranean). Prog Oceanogr 66: 142-156

Sabatés A, Salat J, Masó M (2004) Spatial heterogeneity of fish larvae across a meandering current in the northwestern Mediterranean. Deep-Sea Res I 51:545-557

Sabatés A, Martín P, Lloret J, Raya V (2006) Sea warming and fish distribution: the case of the small pelagic fish, Sardinella aurita, in the western Mediterranean. Glob Change Biol 12:2209-2219

Sabatés A, Salat J, Palomera I, Emelianov M, Fernández de Puelles ML, Olivar MP (2007) Advection of anchovy larvae along the Catalan continental slope (NW Mediterranean). Fish Oceanogr 16:130-141

Sabatés A, Zaragoza N, Grau C, Salat J (2008) Vertical distribution of early developmental stages in two coexisting clupeoid species, Sardinella aurita and Engraulis encrasicolus. Mar Ecol Prog Ser 364:169-180

Salat J (1996) Review of hydrographic environmental factors that may influence anchovy habitats in northwestern Mediterranean. Sci Mar 60(Suppl 2):21-32

Salat J, García MA, Cruzado A, Palanques A and others (2002) Seasonal changes of water mass structure and shelf-slope exchanges at the Ebro Shelf (NW Mediterranean). Cont Shelf Res 22:327-348

Schlitzer R (2004) Ocean Data View software. Available at: http://odv.awi.de/

- Somarakis S, Drakopoulos P, Filippou V (2002) Distribution and abundance of larval fish in the northern Aegean Sea - eastern Mediterranean - in relation to early summer oceanographic conditions. J Plankton Res 24:339-357

Theocharis A, Georgopoulos D, Lascaratos A, Nittis K (1993) Water masses and circulation in the central region of the eastern Mediterranean: eastern Ionian, south Aegean and northwest Levantine, 1986-1987. Deep-Sea Res II 40: 1121-1142

Tsikliras AC, Antonopoulou E (2006).Reproductive biology of round sardinella (Sardinella aurita) in the north-eastern Mediterranean. Sci Mar 70:281-290

Twatwa NM, van der Lingen CD, Drapeau L, Moloney CL, Field JG (2005) Characterising and comparing the spawning habitats of anchovy Engraulis encrasicolus and sardine Sardinops sagax in the southern Benguela upwelling ecosystem. Afr J Mar Sci 27:487-500

van der Lingen $C D$, Hutchings L, Merkle D, van der Westhuizen JJ, Nelson J (2001) Comparative spawning habitats of anchovy (Engraulis capensis) and sardine (Sardinops sagax) in the southern Benguela upwelling ecosystem. In: Kruse GH, Bez N, Booth T, Dorn M and others (eds) Spatial processes and management of marine populations. University of Alaska Sea Grant, Fairbanks, AK, p 185-209

Vargas-Yáñez M, Salat J, Fernández de Puelles ML, LopezJurado JL, Pascual J, Ramirez T, Cortes D, Franco I (2005) Trends and time variability in the northern continental shelf of the western Mediterranean. J Geophys Res 110: C10019, doi:10.1029/2004JC002799

> Wang DP, Vieira MEC, Salat J, Tintoré J, La Violette PE (1988) A shelf/slope frontal filament off the northeast Spanish coast. J Mar Res 46:321-332

Yentsch CS, Menzel DW (1963) A method for the determination of phytoplankton chlorophyll and phaeophytin by fluorescence. Deep-Sea Res 10:221-231

Zeeberg J, Corten A, Tjoe-Awie P, Coca J, Hamady B (2008) Climate modulates the effects of Sardinella aurita fisheries off Northwest Africa. Fish Res 89:65-75 